\title{
The Effect of Regional Socio-Economic Factor on Development of Heterogeneous Urban Contexts; Case Study: Bandar Abbas City
}

\author{
Mohammad Reza Daroudi ${ }^{1}$, Sania Sami ${ }^{2}$ \\ ${ }^{1}$ Department of Architecture and Urban Planning, Young Researchers and Elite Club, Yadegar-e-Imam Khomeini (Shahre-Rey) Branch, \\ Islamic Azad University, Tehran, Iran \\ ${ }^{2}$ Department of Architecture and Urban Planning, Science and Research Branch-Qeshm, Islamic Azad University, Qeshm, Iran \\ Email: Daroudi@Live.com
}

How to cite this paper: Daroudi, M.R. and Sami, S. (2016) The Effect of Regional Socio-Economic Factor on Development of Heterogeneous Urban Contexts; Case Study: Bandar Abbas City. Journal of Building Construction and Planning Research, 4, 190-200.

http://dx.doi.org/10.4236/jbcpr.2016.43012

Received: July 16, 2016

Accepted: September 11, 2016

Published: September 14, 2016

Copyright $\odot 2016$ by authors and Scientific Research Publishing Inc. This work is licensed under the Creative Commons Attribution International License (CC BY 4.0).

http://creativecommons.org/licenses/by/4.0/ (c) (i) Open Access

\begin{abstract}
Heterogeneous urban development of Iran during current decades along with ineffectiveness of urban planning system and shortcoming of national development programs and land use planning have led to many problems of urbanism in Iran so that heterogeneous and old contexts can be named as one of the problems in this field. Urban decay is one of the serious and inevitable problems of urban management in all countries. This study has been conducted to analyze and assess the effect of regional factors on development of problematic urban contexts emphasizing on socio-economic indicators in Bandar Abbas City. Having urban macro-indicators at regional and country level, Bandar Abbas City faces various physical problems which problematic and old contexts are the most important of them that cover an area of 1033 hectares. Economic issues and heterogeneity within social contexts have expanded the mentioned problem in addition to physical problems. Methodology of this study has been analytical-descriptive, data collection method of documentary information has been gathered from relevant administrative organization such as Statistical Center of Iran, the Municipality and the Ministry of Housing and Urban Development, and survey data has been collected through 90 questionnaires. According to the obtained results of this study, it could be found that social, economic, political and managerial factors have had effects on formation of heterogeneous contexts and extensive migration during the current years has expanded problematic contexts of Bandar Abbas due to its specific regional conditions. Moreover, the obtained results of this study indicated that heterogeneous contexts had some features including fine-grained, inadequate access network, impervious, inferior materials and poor construction of buildings and lack of necessary infrastructure.
\end{abstract}

\section{Keywords}

Heterogeneous Context, Bandar Abbas, Regional Management, Informal Settlement 


\section{Introduction}

Human settlement has built civilization during historical process of societies' development. Cities have been the center of this civilization as the prior level of settlement in this process. Prospect for global development indicates that the role of human settlement is continued in order to build and preserve those productive and sustainable cities with an appropriate environment for production, living and human activities. Informal settlement is urbanization with serious problem that has been an important reason to make cities unsustainable especially in developing countries, while this factor is increasing based on the global observations. It is obvious that informal settlement is a state of urban poverty forming within or beside cities (especially large cities) without any construction permit and formal program of urbanism, in which a large number of low-income people with poor-quality life are living. This is the phenomenon recognized under the titles such as suburbanization, informal settlement, spontaneous and disorganized settlement and squatter communities. There are various factors affecting heterogeneous contexts at macro, middle and micro levels so that these factors can be divided into social-demographic factors, economic and environmental factors, and political and managerial factors. Prepared development programs before revolution (fourth and fifth programs) and important role of Bandar Abbas as a port for import and export of goods have had an important role in urban system and formation of heterogeneous contexts. Moreover, establishment of Bandar Abbas Refinery (1971), establishment of Shaheed Rajaee Port (1971), creation of free trade zone of Qeshm (1990) and development of peripheral countries around Persian Gulf in 90 decade made Bandar Abba transform from a peripheral role to the content of economic transformations, leading to regional investments and migration. Another important factor is related to Islamic Revolution and imposed war. Occurrence of Islamic revolution and forthcoming changes made Bandar Abbas be an important port of Iran. On the other hand, war refugees' entrance and their settlement in poor and low-income areas of cities are socio-economic consequences in Bandar Abbas. In this regard, this study aims to assess the effect of socio-economic factors on formation and expansion of heterogeneous contexts in Bandar Abbas City in order to identify regional factors and propose some solutions to prevent from development of such contexts and other urban contexts.

\section{Materials and Methods}

The issue of heterogeneous contexts has not been taken as a serious issue during current decades but it has been suddenly considered as an important headline of national planning and development documents of country since the past decade. Importance of this issue due to its close relationship with social and mental security and index of national welfare is considered within all development documents of Iran such as 20-years Prospect Document, 5-years Development Programs, regional documents, and municipal decisions made by Islamic Councils of cities. On the other hand, some urban heterogeneous contexts of Iran have been organized while there is not any effective result due to the lack of awareness and information about regional problems. There is not also 
any conducted study to assess and identify inter-regional and extra-regional factors in formation of urban heterogeneous contexts in Bandar Abbas; hence, this study has been conducted to assess and identify the effective factors in creation of heterogeneous contexts in this city because the negative consequences of these contexts can be easily seen in this zone. The various problems caused by heterogeneity in contexts of this city would make it necessary to assess the reasons for expansion of inefficient urban contexts so that such studies would help to discover reasons for expansion and creation of such contexts in cities in order to identify those regions with heterogeneous contexts and provide an effective program. According to world studies and experiences of different countries about urban development and old contexts, this study has been conducted within three important fields of economic, physical-environmental and social fields in accordance with the objective of this paper that is identifying the effective regional factors in formation of heterogeneous contexts of Bandar Abbas City. Accordingly, the mentioned fields have been studied in this study in accordance with some variables and existed problems and objectives.

\section{Theoretical Bases}

Informal settlement is a place in which, there are groups of urban population including rural immigrants with living conditions different with common standards of society and this population is marginalized in different aspects. Lack of life facilities compared to other areas of city has changed such settlements to centers of urban issues and against sustainable human development [1]. Hence, it would be necessary to evaluate the issue of informal settlement in accordance with human values and beliefs coordinated with social interests and stability of settlements and national development [2]. These settlements are results of contemporary rapid urbanism and urban poverty emerging within or around cities with low-income population and informal jobs, which is an aspect of unsustainable development and social harm [3]. Informal settlements are defined as contexts including rural immigrants and urban poor so that these contexts are emerged without permission and official and legal planning of urban development (comprehensive and detailed plans) within or out of legal area of cities. Such settlements do not have ownership document and lack urban infrastructures and services [4]. Turner (1969) has a positive theory about such settlements and considers them as a successful solution for housing problems of urban areas of developing countries. Pine (1977) introduces a similar concept and considers the expansion of illegal settlements because of the urban growth of third world and its relevant issues [5]. Scholars and experts of urban issues have presented various definitions about informal settlements that most of them consider the quality of house and type of ownership as determining factors of informal settlements [6]. Informal settlement is a fact resulted by interaction between social, economic, natural environments and ecologic as a geographical space originated from spatial inequality with undesired effect on urban space that is due to unequal spatial performances in different levels. In fact, informal settlement is a method of residence in which, settlement pattern is a results of various geographical spa- 
tial scales at national levels; in other words, this is a result of weakness of spatial planning at regional and national levels and concentration of desired space on special regions (cities) and making residents leave the undesired space and live in a better space hoping access to a desired life [7].

In general, following reasons in Table 1 can be named in clarification of informal settlement:

According to Barier, urban development has had an equal trend until 1956. At the beginning of 20th century (1900), Iran had a population about 9 million and 86 thousands that 21 percent of them were living in 99 cities and more than 79 percent were migrating to rural communities [8]. At the firs census of population and houses of Iran in 1956, urban population were about 9,997,000 members living in 199 cities that

Table 1. Reasons for informal settlement from different aspects.

Reasons

Structural and macro reasons

Non-structural and case reasons
Relevant factors

- Increasing growth of population during current decades and migration of rural labor force to cities especially large cities;

- Lack of policies and coordinated strategies of economic, social and planning development at regional and macro level;

- Intensified inequality within distribution of power, wealth and income sources and presence of regional inequalities;

- Lack of socio-economic strategies in order to enabling participation of people to create appropriate conditions for immigrants;

- Inefficiency of management system and planning of urban and regional development.

- Lack of appropriate development of educational system of professional and technical system in urban and rural areas and lack of appropriate places for training the required jobs in poor areas of cities;

- Lack of programs of social and cultural development to enable people at personal and social levels within squatter areas in order to have economic and social self-reliance in new urban life;

- Lack of culture in urban community to attract and emerge these groups in common urban contexts;

- No pay attention to investment on low-price houses in poor and sub-urban areas of large cities;

- Lack of comprehensive approaches, programs and policies in urban planning system and management;

- Lack of appropriate policy for spontaneous organizations of people in poor urban areas and lack of support of urban management and organizations from formation of associations and non-governmental organizations and social institutions (under the supervision of Hossein Kakooee et al., 2003, introduction of scientific secretary);

- Lack of access to formal systems of credits and mortgages for low-incom people especially those who work in informal sector;

- Presence of illegitimate bands and land traders along with inability to supervise and control construction especially in spaces among cities;

- Lack of institutes to aggregate the sources of low-income groups and lack of governmental supports from housing (Sarrafi, 2002, P. 7)

- Some scholars consider this phenomenon because of urban and rural migration and sufficient supply of urban housing (Esmaeelpoor, 2010). 
was $31 / 4$ percent of the whole population while the ratio of urban population has been increased to 68/4 percent in half a century later in 2006 and number of cities passed through the thousands members. Meanwhile, development of urbanism in Iran has not been equal like other developing countries and large cities have had the most shares in this distribution (Statistical Center of Iran, population and housing census of years 1956-2006). During current centuries, the growth of Bandar Abbas has been pendular so that the area known as old city has been formed and then the growth of city has been tended to the west of this area (Area of Kolah Farangi) and then is continued to the east of area and this trend has been repeated until today and Bandar Abbas has been formed. In addition to the change of indigenous context of city, there has been undeniable change in spatial structure of city [9]. The area in which, Bandar Abbas is located is about 5300 hectares developing linearly along the coast [10] (Figure 1).

The most important issues in Bandar Abbas have been the increasing migration to Bandar Abbas City (entry of more than 80,000 members to city) during current decades and expansion of informal settlement (settlement of $31 \%$ of population of Bandar Abbas City in informal settlements of city) so that there have been some solutions in this field. There are various factors affecting the growth and formation of informal settlement at macro, middle and micro levels and these factors are classified as social-demographic factors, economic factors, environmental factors and political-management factors [11]. Land reforms (1963) can be considered as the start point among various factors changing the pattern of development and reconstruction in Hormozgan Province and Bandar Abbas city. Land reforms have created basic changes in national and regional economy that have had effects on the reconstruction of Bandar Abbas City in different dimensions. Land reforms in rural areas have changed the life style in both urban and rural regions and growth of unequal urbanism due to the migration of villagers to urban areas has been the first consequence of land reforms. The process of investment attraction had been increased during 1973-1974 in Bandar Abbas because of increase in oil

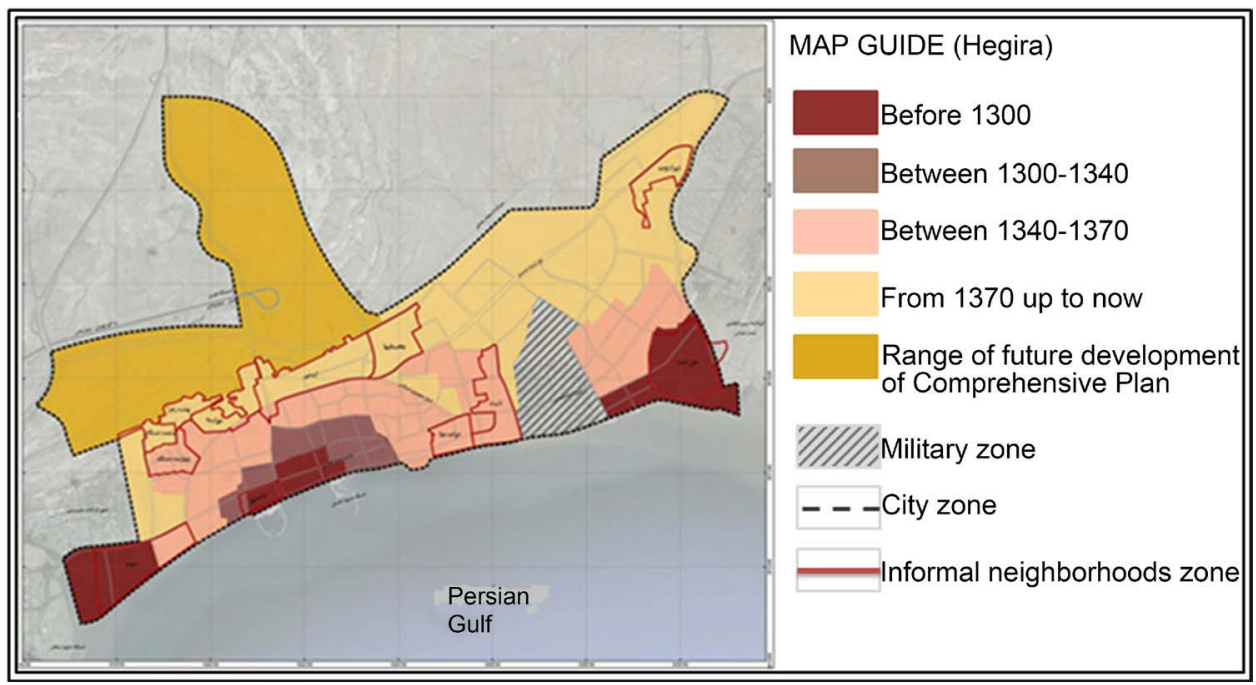

Figure 1. Growth and development trend of Bandar Abbas, 2006. 
price. The increased oil price not only rejected the planning system but also deeply affected the economy through entering the unplanned money of oil to the economic structure of Iran. The mentioned increase in oil price had some effects on development of ports and economic development. It should be mentioned that rural and urban migration has been the first consequence of this development [9]. An addition to mentioned socio-economic transformation some other factors should be mentioned such as provided development programs before revolution (fourth and fifth programs) and the role of Bandar Abbas as an important port for import and export of goods through shipping. Moreover, establishment of Bandar Abbas Refinery (1971), establishment of Shaheed Rajaee Port (1971), creation of free trade zone of Qeshm (1990) and development of peripheral countries around Persian Gulf in 90 decade made Bandar Abbas to transform from a peripheral role to the content of economic transformations leading to regional investments and migration. The consequence of this program was an attraction of regional and national investments in Bandar Abbas City that created many job opportunities for both residents and immigrants compared to other provinces so that there were a large number of labor forces entering to Bandar Abbas. Occurrence of Islamic revolution (1978) and imposed war (1980-1988) have been other factors with serious social, economic and political effects on Bandar Abbas City. Occurrence of Islamic revolution and its transformations made Bandar Abbas as the most important port of Iran [12]. One of the goals of import and export of goods through shipping and commercial system in this city was to create job opportunities based on business so that special social and economic groups were attracted. Hence, Bandar Abbas City was a place for migration for various reasons. Entrance of immigrants of war zones was another factor that caused an increase in population of city. These immigrants were forced to permanent residence in city [13]. On the other hand, economic weakness of such immigrants made them to live in low-price regions. The most indigenous immigrants that were residents of villages had low-level socio-economic position. In some cases, migration pattern was prior like old and tribal migrations such as Ouzis, Chahestanies, Laries, etc. [14].

This type of migration pattern is different with those immigrants migrating in order to find job in Bandar Abbas. These immigrants are able to rent or buy a house in middle class regions of city. Accordingly, expansion of informal settlements is related to those immigrants who are looking for job and life in Bandar Abbas. These structural and macro transformations in social, economic and political fields beside the weakness of land planning of southern region of Iran and inappropriate planning at macro levels that are not coordinated with existed infrastructures led to improper planning of middle levels in new structures and then rapid and unequal special, physical, economic and demographic changes formed Bandar Abbas. Urban management was surprised due to the demographic changes, increased migration and growth of urbanism. Majority of immigrants were low-income villagers looking for job; hence, urban management faced three problems as follows:

1. Lack of ability of urban management to settle low-income population. 
2. Lack of job opportunities and coordinated entrepreneurship with demand.

3. Lack of appropriate infrastructures and services coordinated with increased population.

The rapid and abnormal growth of demand for urban land caused increase in price of lands and housing so that a poor and low-income population was formed in city. The mentioned population was not supported by social security system and this shortcoming caused an increase in urban poverty and increased low-income population [15]. Financial poverty of mentioned class beside their vulnerability, isolation and mental and physical poverty, as well as inability in social negotiations have created poverty trap and those people who are in this trap are forced to choose social and spatial separation. Poverty trap is a defected cycle producing sub-urbanism in Bandar Abbas City. Accordingly, informal settlements in Bandar Abbas City have been the consequence of an urban, regional and national process while it has been proved that elimination of informal settlement not only resolve this issue but also makes it more complicated unless a serious harm threatens residents. Prevention from migration is not practical and executive in accordance with macro policy-making emphasizing on development of Bandar Abbas City and this issue can be solved based on local planning especially with managerial and executive methods such as creation of job opportunities, serving, and supply of housing for low-income population, etc.

\section{Results}

One of the most important and effective parameters in formation of informal settlements in Bandar Abbas is the issue of cost of housing such as costs of land and construction. Features of a house and its cost are the most considerable issue to choose residence place when immigrants enter to a city. In Bandar Abbas, some factors such as climate and whether conditions has caused an increase in construction cost and production time and in accordance with land use and tendency of residents towards one-story houses have led to an increase in price of land in this city. Another important point is related to the high cost of construction in Bandar Abbas City as the biggest center for informal settlement (more that national standard). This issue has been one of the reasons for expansions of informal settlement on Bandar Abbas and other similar cities. Meanwhile, the maintenance cost of house in this city is more than national standard in accordance with specific environmental conditions and humidity in hot seasons. In addition to mentioned factors, the poor quality of construction based on the engineering principles has increased the maintenance cost of housing in sub-urban contexts of Bandar Abbas. It would be necessary to have a broad economic view Bandar Abbas City and Province in order to planning informal housing units. In an economic analysis, the origin of informal housing units can be explained through two different methods:

1. Lower levels of income in a community that can increase informal housing units.

2. The method in which, growth is not considered but development patterns are considered as reasons for unequal distribution of income and wealth, sub-urbanism and 
informal settlement.

In Bandar Abbas City, the price of housing units of heterogeneous areas is lower than other areas of city but point wise assessment of price in areas with higher values indicates that this higher value can effect on housing units so that the price of housing in some informal areas is increased. For instance, the areas of Nakhl Nakhoda adjacent to Southern Golshahr and University Street and areas of Nayband and Isini adjacent to central streets of the city has caused an increase in price of housing units in these areas. The overall assessment of price dispersion of residential and rental houses in the neighborhood is evaluated in this part of study. The highest price of residential properties in informal neighborhoods was firstly related to Nayband area then to Isni and Posht Shahr. The maximum price of each square meter of housing units is related to Isini area and then neighbors of Nayband, Soru and Nakhl Nakhoda have had the maximum price of housing units. As it was mentioned, the maximum price level of these areas is related to neighbors adjacent to areas of Golshahr in Nakhl Nakhoda and Bazaar in Nayband and Soru. The minimum level of price of housing units is related to areas of Chaharsad Dastgah, Tohid Town and Behesht Zahra. The rental price of housing units in mentioned areas is similar to the sale price of residential properties. The highest rental rate is related to areas of Nayband, Khaje Ata and Nakhl Nakhoda. The lowest rental rate is related to areas of Chaharsad Dastgah, Tohid Town and Behesht Zahra that indicates quality and low economic level of households in these areas. According to social dimension, 40 percent of population of Bandar Abbas is living in informal settlements. There has been an increase in number of immigrants from Hormozgan to Bandar Abbas during 1986 to 2006. In addition to inter-provincial migration, there have been immigrants from other provinces to this city. Migration pattern has increased the need of housing units. This migration pattern has led to growth of informal units due to the lack of effective demand for housing and low-income immigrants with no expertise. It means that the number of low-income families has been increased in this city. In general, informal settlements of Bandar Abbas City have broad family size because of social and demographic reasons. Comparative study of family size within informal settlements indicates that areas of Nyband and Chaharsad Dastgah have had the most level of family size (4 to 6 members) in Bandar Abbas City. Sheshsad Dastgah is the only area that is equal with average of Bandar Abbas City.

\section{Conclusions}

Rapid changes of Bandar Abbas City and its expansion during current decades have created sub-urban neighbors and informal settlements in this city so that these areas such as Kamarbandi has been expanded from southern west to north, eastern south and center of the city. Regional and national macro policies have made Bandar Abbas City be the most important port in southern coasts of Iran through defining multiple roles and functions of this City. This issue has developed this city through direct and indirect methods and entrance of a large population to the city is the first consequence of such urban development. In accordance with special situation of Bandar Abbas City, these 
policies at national and international level are doable, but it would be necessary to make policies coordinated with development changes with large scale at national and international level in order to reduce the undesired effects of such urban development at micro levels. It seems that this type of attitude has not been considered as an important issue as well as macro plans and programs. It would be possible to optimize and reconstruct the old contexts through reinforcement of local institutes and participating plans. Two principals have the basic role in today urbanism that is based on global knowledge and experience. The mentioned principles are as follows: first, public participation in providing, implementation and operation of projects; second, passing the sustainable development path with a human-based approach. The two mentioned principles have been accepted in all urban systems and are considered as the only possible method in formal documents of urbanism in developed countries in order to solve the ecologic crisis and social inequalities.

The following actions should be done by government, public and private sectors in order to strengthen local institute within heterogeneous context of Bandar Abba City:

- Allocating budget of the plan of Ameri area to local preparation to establish local entity and possibility of contact with people.

- Tax and charge exemption to attract investment and partnerships of private and public sectors and housing cooperative.

- Granted concessions by the banks and Housing Bank.

- Forming local housing cooperation, integration of lands, collection buildings and training durable and inexpensive constructing methods for volunteers.

- Signing a contract with the local participation institution to entrust the implementation of a number of measures which will strengthen financial institutions and create local jobs.

- Legalization of local entity (statue, registration, $\cdots$ ).

- Persistence agreement with this entity in the field of executive plans, programs and projects and providing simple procedures to facilitate activities of this entity.

In accordance with the lack of infrastructural establishments within heterogeneous context of Bandar Abbas City, it is recommended:

1. Since the heterogeneous context has created an ugly face of this city while beauty can affect on view of tourists, it is recommended Bandar Abbas Municipality help non-governmental organizations to organized facade and urban context (street, valley, $\cdots$ ) by using elements such as green spaces and urban furniture.

2. The obtained results of this study indicate that appropriate credits and budgets are essential to regenerate heterogeneous context of Bandar Abbas City so that lack of efficient budget is the most important reason for lack of attention to optimization of such contexts. Hence, it is recommended to allocate government budgets to reconstruct heterogeneous contexts of this city.

3. It is recommended for effective financial institutes of government sector (banks and cooperatives) to grant banking facilities to residents of heterogeneous contexts in order to attract financial participation of organizations and institutions. 
4. According to the obtained results of this study, the big part of studied houses and buildings is constructed by unstable and low-resistance materials. Hence, it is recommended for relevant organizations in collaboration with engineering organization to provide technical training to residents of studied building.

5. It is recommended for non-governmental organizations to emphasize on participation of residents in organizing old contexts in order to prevent from illegal constructions.

6. Creating a sewage system for disposal of domestic sewage and development of urban water supply with essential services such as electricity, and health is the needs of residents of heterogeneous contexts in the city of Bandar Abbas, which recommends that the authorities should pay attention to them.

\section{References}

[1] Bigdeli, D. (2005) Organizing Informal Settlements of Studied Sample of Street Fatemieh Zanjan City. MA Thesis of Geography and Urban Planning, University of Zanjan, Zanjan.

[2] Esmaeilpoor, N. (2009) The State of Housing in Informal Settlements and Provide Regulatory Strategies Case Study: Hassan Abad Neighborhood of Yazd. Journal of Regional Studies, No. 4, 96-97.

[3] Ahmadian, M.A. (1992) Sub Urbanism. Faculty of Literature and Humanities University of Mashhad, Vol. 25.

[4] Roosta, M. (2009) Issue of Informal Settlements in the Iran, Approaches, Challenges and Strategies. Commission Special Session of Infrastructure and Production, the Expediency Council. http://maslahat.ir/Commissions/Fundamental/DocLib/Organization.aspx

[5] Athari, K. (2005) Marginalization in Iran, Causes and Solutions. Proceedings of the 2nd Seminar Housing Development Policies in Iran, Vol. I, 54.

[6] Kamali, M., Zulfaghari, M. and Ahmadi, E. (2010) The Necessity of Organizing Informal Settlements by Establishing a Comprehensive Campaign of Organizing and Empowerment and NGOs in the Form of CBO. The Rehabilitation and Reconstruction Organization. www.cbsh.ir

[7] Daviran, I. (2009) Issue of Marginalization of Informal Settlements and Political Economy of Space. The National Conference of Informal Settlements Challenges and Strategies, March 2009, 3.

[8] Statistical Center of Iran (2006) General Census of Population and Housing.

[9] Mahdavi, S.M. (2009) Examining the Old Context and the Historical City of Bandar Abbas. MA Thesis, Islamic Azad University Rey Branch, Tehran.

[10] Pooraghaee, A. (2004) Analysis of Informal Settlements in the City of Rasht and Appropriate Ways to Improve It. MA Thesis of Geography and Urban Planning, Yazd University, Yazd.

[11] Mahmoudian, S. (2010) The Effects of Physical Development and Strategies for Organizing and Restoration of the Old City of Bandar Abbas. PhD Thesis in Sociology, Tehran University, Tehran.

[12] Engineers of Strategy Consultant (2010) Comprehensive Plan of Strengthening Informal Settlements in Bandar Abbas, Hormozgan Province Housing and Urban Development. Ministry of Roads and Urban Development News. http://news.mrud.ir/

[13] Tavasoli, M. (2001) Terminology of Modernization and Urban Improvement of Hormozgan 
Province. Journal of 7 Shahr, Civiland Urban Upgrading, No. 2, 85.

[14] Miladi, M. (2011) Organizing Urban Old Areas (Case Study 600 Dastgah of Bandar Abbas). MA Thesis, Islamic Azad University Science and Research Branch, Tehran.

[15] Koochak Khoshnevis, A.M. (2004) Crisis Roundtable of Urban Historical Contexts. Journal of Municipalities, 14, 76-79.

Submit or recommend next manuscript to SCIRP and we will provide best service for you:

Accepting pre-submission inquiries through Email, Facebook, LinkedIn, Twitter, etc. A wide selection of journals (inclusive of 9 subjects, more than 200 journals)

Providing 24-hour high-quality service

User-friendly online submission system

Fair and swift peer-review system

Efficient typesetting and proofreading procedure

Display of the result of downloads and visits, as well as the number of cited articles Maximum dissemination of your research work

Submit your manuscript at: http://papersubmission.scirp.org/ 